\title{
FILM KOMEDI RUKUN KARYA: STRATEGI SENIMAN TRADISI MEMPERTAHANKAN EKSISTENSI PADA ERA PANDEMI
}

\author{
Panakajaya Hidayatullah \\ No. Tlp.: +62 899-0523-702, E-mail: panakajaya.hidayatullah@gmail.com \\ Dwi Haryanto \\ E-mail: dwiharyanto.sastra@unej.ac.id \\ Dewi Angelina \\ E-mail: dewi.fib@unej.ac.id \\ Fakultas Ilmu Budaya Universitas Jember, Indonesia \\ Jalan Kalimantan No. 37 Krajan Timur, Sumbersari, Kabupaten Jember
}

\begin{abstract}
ABSTRAK
Penelitian ini mengkaji strategi seniman tradisi dalam mempertahankan eksistensinya pada era pandemi. Penelitian difokuskan pada kelompok kesenian tradisi Ketoprak Madura Rukun Karya yang berasal dari Kabupaten Sumenep. Pada masa pandemi, kelompok Rukun Karya mengalami dampak yang cukup signifikan, dengan dibatalkannya beberapa daftar pementasan selama setahun. Kelompok ini kemudian mampu membalikkan kondisi keterpurukan melalui kesuksesannya dalam memproduksi konten film komedi Rukun Karya. Penelitian ini merupakan jenis penelitian kualitatif dengan pendekatan multidisipliner. Metode pengumpulan data dilakukan melalui teknik observasi partisipatoris, pengamatan mendalam, wawancara, dan studi literatur. Temuan yang dihasilkan dari penelitian ini antara lain (1) Rukun Karya melakukan peralihan mode pertunjukan dari ketoprak Madura menjadi film komedi yang memiliki dua jenis bentuk penceritaan, yakni cerita adaptasi (gaya ketoprak, sastra Timur-Tengah, sejarah, dan televisi) dan cerita realitas kehidupan masyarakat Madura; (2) peralihan mode pertunjukan dari ketoprak menjadi film komedi didasari oleh mekanisme industri (budaya) melalui media (Youtube), yakni strandardisasi, komodifikasi,dan massifikasi; dan (3) peralihan mode pertunjukan berdampak pada perubahan cara penyajian dan cara menikmati sajian pertunjukan, beberapa contohnya ialah hilangnya interaksi seniman-penonton, serta digantikannya cita rasa dalam menikmati sajian pertunjukan secara kolektif menjadi cita rasa yang privat dan sangat individualistik.
\end{abstract}

Kata Kunci: film komedi Rukun Karya, strategi kebertahanan seni tradisi, pandemi, Madura, Youtube

\section{ABSTRACT}

Judul b Inggris. This research examines the strategy of traditional artists in maintaining their existence in the pandemic era. The research focused on the traditional art group Ketoprak Madura Rukun Karya from Sumenep Regency. During the pandemic, the Rukun Karya group experienced a significant impact, with several lists of performances being canceled for a year. This group was then able to rise through the production of the Rukun Karya Comedy Film content. This research is a qualitative research with a multidisciplinary approach. Methods of data collection are carried out through participatory observation techniques, in-depth observations, interviews, and literature studies. The results of this study include 1) Rukun Karya shifting its performance mode from Madura ketoprak to comedy films which have two types of storytelling, namely adaptation stories (ketoprak style, Middle Eastern literature, history, and television) and the reality stories of Madurese life; 2) The shift in the mode of performance from ketoprak to comedy film is based on the industrial (cultural) mechanism through the media (youtube), namely standardization, commodification and massification; 3) The shift in performance modes has an impact on changes in the way of presentation and the way to enjoy performance offerings, some examples are the loss of artist-audience interaction, as well as the replacement of the sense of enjoying collective performances into a private and highly individualistic sense.

Keywords: Rukun Karya Comedy Film, Traditional Arts Sustainability Strategy, Pandemic, Madura 


\section{PENDAHULUAN}

Pandemi Covid-19 yang datang ke Indonesia pada awal tahun 2020, mengubah seluruh tatanan ekosistem seni pertunjukan di tingkat masyarakat (Septiyan, 2020). Kebijakan pembatasan fisik (phisical distancing) yang dikeluarkan oleh pemerintah memberikan dampak yang cukup besar terhadap kehidupan para seniman. Di antara kelompok seniman, yang paling rentan terkena dampak dari kebijakan ini ialah kelompok seniman tradisional. Sebelum adanya pandemi saja, mereka harus berjuang menghidupi keseniannya yang mulai ditinggalkan dan dilupakan oleh masyarakat penontonnya. Kemajuan zaman dan teknologi yang semestinya memudahkan kehidupan manusia pada kenyataannya tidak begitu ramah untuk kehidupan seni tradisional. Seringkali dan kebanyakan seniman tradisional tidak mampu beradaptasi dengan kemajuan zaman dan teknologi sehingga mereka tidak mampu survive dengan arus modernisasi yang cepat (Hidayatullah, 2020b). Kini, ruang pertunjukan dan apresiasi terhadap seni tradisional terbatas. Umumnya seni tradisi hidup di wilayah pedesaan, yang jauh dari kota. Ia bertahan hidup dari sistem tanggapan, dari hajatan satu ke hajatan lainnya. Ihwal ini menjadi bertambah buruk ketika pandemi Covid-19 melanda. Satu-satunya kesempatan mereka untuk pentas dan beraktivitas dibatasi oleh pemerintah karena keadaan yang mendesak. Mereka tidak bisa menolaknya. Tidak ada aktivitas keramaian, tidak ada pentas hajatan, dan tidak ada lagi ruang yang memberikan kesempatan kepada mereka untuk pentas.

Tidak adanya pentas selama hampir setahun lebih membuat eksistensi seni tradisional di beberapa daerah mulai goyah. Beberapa kelompok seni tradisi bahkan ada yang nyaris bubar karena bangkrut dan kehabisan modal sehingga terpaksa menjual perangkat pertunjukannya (Komunikasi Pribadi dengan Trisnawati, 12 November 2020). Di tataran yang lebih kecil, kehidupan senimannya kini juga tidak menentu. Biasanya mereka bekerja dengan mengandalkan seni sebagai satu-satunya lahan mencari nafkah. Covid memaksa mereka untuk meninggalkan pekerjaan yang dicintainya dan beralih mencari pekerjaan lain yang bisa menghidupi mereka. Sebagai contoh pada salah satu kasus pemain seni tradisional di Sumenep Madura bernama Bapak Suharjono (Enjo), dari kecil Suharjono sudah terbiasa hidup di bawah pentas ketoprak. Dia tidak punya bayangan bekerja di bidang yang lain. Bagi dia, ketoprak adalah dunia dan hidupnya. Covid benar-benar memukul kehidupannya, sekarang dia terpaksa menjadi buruh tani di sekitar tempat tinggalnya (Komunikasi Pribadi dengan Fendi, anak Bapak Suharjono, 12 Februrari 2021). Bapak Suharjono adalah satu dari sekian banyak para seniman tradisional yang merasakan dampak dari pandemi Covid-19.

Di tengah krisisnya eksistensi seni tradisional, akhir-akhir ini muncul beberapa kelompok seni tradisi yang mampu secara perlahan keluar dari kondisi keterpurukan akibat pandemi. Salah satunya adalah rombongan (istilah lokal penyebutan kelompok/organisasi seni tradisional Madura) seni tradisional ketoprak Madura Rukun Karya di Sumenep Madura. Rombongan ketoprak Rukun Karya adalah salah satu organisasi yang cukup kuat eksistensinya, tidak hanya di lingkungan Sumenep, tetapi juga di lingkungan masyarakat Madura di luar Pulau Madura, seperti di Situbondo, Probolinggo, dan Bondowoso. Pada masa awal pandemi, rombongan ini juga mengalami keterpurukan. Aturan pemerintah yang ketat memaksa mereka membatalkan seluruh jadwal pentas selama satu tahun. Tidak hanya itu, mereka juga harus mengembalikan uang muka yang sudah diterima di awal. Sebelum pandemi, rombongan ini cukup sibuk dalam menggelar pentas, para panjhâknya (personel) rata-rata merupakan pemain profesional yang artinya hanya mengandalkan pekerjaan seniman sebagai mata pencahariannya. Pandemi membuat banyak panjhâknya kehilangan pekerjaan tetapnya. Mereka harus mencari pekerjaan lain sebagai dampak dari malapetaka tersebut. Sebagian ada yang bekerja di sawah, berdagang, menjadi makelar, dan kerja serabutan (Komunikasi 
Pribadi dengan Fendi, anak Bapak Suharjono, 12 Februrari 2021).

Persoalan ini kemudian mulai menemukan titik terangnya ketika Dendi, anak dari juragan (pimpinan) Rukun Karya mulai bereksperimen dan mencoba peruntungan di dunia digital Youtube. Awalnya ia membuat kanal Youtube bernama Dendi Ruka. Ruka adalah singkatan dari Rukun Karya sebagai penanda identitas dirinya. Dendi mengisi beberapa konten-konten video dokumentasi Rukun Karya ketika pentas sebelum pandemi dan beberapa kegiatan vlog-nya. Hingga kemudian ia bersama ayahnya, Edi Suhandi, dan beberapa rekannya di Rukun Karya mulai serius menggarap konten Film komedi berdurasi sekitar 20-30 menit. Konten-konten film komedi Rukun Karya mendapat banyak respons dari penggemar setianya baik di Madura maupun di luar Madura. Tidak butuh waktu lama, kanal Youtube Dendi Ruka mendapat banyak pengikut dan menemukan fans 'fanatik'-nya kembali. Rata-rata pengikutnya ialah fans ketoprak Rukun Karya yang sudah biasa menonton pertunjukan mereka secara live. Saat ini mereka mulai beradaptasi untuk menikmati sajian pertunjukan Rukun Karya secara daring. Alih media yang dilakukan oleh rombongan Rukun Karya adalah strategi yang cukup berhasil dan efektif dilakukan di masa pandemi.

Upaya inisiatif yang muncul dari tangan dingin rombongan Rukun Karya cukup menarik untuk dibahas dan diuraikan, karena tidak banyak kelompok seni tradisi yang mampu keluar dari keterpurukan akibat pandemi. Bagi kelompok seni 'urban' atau 'modern' (masyarakat perkotaan) yang sebagian besar senimannya menguasai peranti dan teknologi modern, tidak butuh waktu lama untuk beradaptasi dan mengalih mediakan proses kreatifnya ke media daring, tetapi berbeda konteks dengan kondisi masyarakat seni tradisi di lingkungan budaya Madura. Senyampang yang penulis amati, tidak banyak seniman tradisi Madura yang mampu survive dalam tekanan pandemi. Rombongan Rukun Karya adalah sebuah pengecualian dari sekian banyak kelompok seni tradisi yang mengalami nasib buruk. Kendati pandemi tetap berlangsung, mereka tetap berkarya dan tidak pernah kehilangan eksistensinya di masyarakat.

Proses peralihan mode pertunjukan dari panggung ke layar virtual dapat dikatakan menjadi solusi alternatif, tetapi proses alih wahana dan media tersebut tetap memiliki konsekuensikonsekuensi artistik dan perubahan dalam cara menikmati penyajian. Perubahan mode pertunjukan menegosiasikan pelbagai aspek untuk dikonstruksikan ulang ke media yang baru, aspek apa yang harus dipertahankan, diganti atau bahkan dikolaborasikan. Konten Youtube yang sederhana tentu saja tidak akan mampu untuk merepresentasikan kompleksitas pertunjukan ketoprak Madura yang berdurasi nyaris semalam suntuk. Perubahan bentuk, gaya, dan penyajian adalah ihwal yang niscaya terjadi dalam proses peralihan mode pertunjukan.

Fenomena mengenai strategi pemertahanan seni tradisi melalui strategi peralihan mode pertunjukan tidak hanya menarik untuk dibahas dan diteliti karena proses perubahannya, tetapi juga karena keterkaitannya dengan situasi saat ini. Sebab, hingga saat ini para seniman tradisi masih merasakan problem yang belum terselesaikan dengan baik di akar rumput, khususnya yang berhubungan dengan kehidupan seni tradisional pada masa pandemi. Artikel ini secara khusus akan menguraikan persoalan mengenai (1) strategi kebertahanan rombongan Rukun Karya pada masa pandemi, (2) konsekuensi-konsekuensi artistik yang terjadi pada proses alih mode pertunjukan, (3) bagaimana mereka menyiasati konsekuensi artistik tersebut, dan (4) bagaimana perubahan konsep penyajian pertunjukannya.

\section{METODE PENELITIAN}

Penelitian ini adalah jenis penelitian kualitatif dengan menggunakan pendekatan multidisipliner. Adapun pengambilan data dilakukan menggunakan beberapa Teknik, yakni pengamatan partisipatoris pada pertunjukan Ketoprak Madura di Situbondo, metode wawancara kepada beberapa 
informan yang berkaitan dengan Rombongan Rukun Karya (seniman, dan keluarga seniman), pengamatan mendalam pada film komedi Rukun Karya versi digital di Youtube (kanal Youtube Dendi Bogan dan Edi \& Dimas RUKA), serta kajian literatur yang membahas perihal seni tradisional ketoprak. Data yang terkumpul diklasifikasi berdasarkan jenis datanya, kemudian direduksi dan disesuaikan dengan kebutuhan penelitian. Data yang telah direduksi kemudian dianalisis menggunakan pelbagai teori seni pertunjukan, alih wahana, dan kajian budaya (postkolonialisme).

\section{HASIL DAN PEMBAHASAN}

\section{Bertahan dari Era Kolonial Hingga Milenial}

Rukun Karya adalah salah satu kelompok seni tradisional ketoprak Madura yang tersohor di kalangan komunitas Madura. Rukun Karya eksis hampir di seluruh wilayah kebudayaan Madura, tidak hanya di daerah Sumenep tetapi juga di beberapa daerah di Jawa Timur seperti Situbondo, Bondowoso, Probolinggo, dan Banyuwangi. Pertunjukan ketoprak Rukun Karya selalu memikat hati para penontonnya. Hampir di setiap daerah terdapat komunitas penggemar (fans) yang fanatik, yang datang setiap kapan pun dan di mana pun kelompok ini pentas. Rukun Karya juga dianggap sebagai patron dari gaya seni tradisi ketoprak Madura di Situbondo, ia selalu menjadi contoh dan rujukan estetika oleh kelompok seni tradisi ketoprak yang lain (Hidayatullah, 2017).

Di lingkungan masyarakat Madura, seni ketoprak biasa disebut dengan tabbhuwân. Mereka tidak biasa menyebut dengan seni ketoprak dalam percakapan sehari-hari, istilah tabbhuwân jauh lebih produktif diucapkan dan digunakan oleh masyarakat Madura. Secara etimologis, tabbhuwân dalam bahasa Madura memiliki arti tabuhan, secara konteks budaya ia dimaknai sebagai sebuah entitas seni pertunjukan yang menggunakan instrumen musik tetabuhan gamelan Madura. Terminologi tabbhuwân tidak hanya dipakai untuk menyebut pertunjukan ketoprak Madura, tetapi juga digunakan untuk menyebut semua jenis seni pertunjukan yang menggunakan (berhubungan dengan) musik iringan gamelan Madura seperti topèng kertè dan loddrok (Hidayatullah, 2020a; Yoandinas, Hidayatullah, Farhan, Imron, \& Martiningsih, 2020).

Dalam konteks ketoprak Rukun Karya, masyarakat Madura di Situbondo dan sekitarnya biasa menyebut dengan istilah tabbhuwân Rukun Karya. Rombongan Rukun Karya bisa dibilang sebagai 'seni populer'-nya masyarakat Madura di Situbondo. Pertunjukannya selalu dinantikan oleh sebagian besar pencinta seni tabbhuwân, mereka rela menempuh perjalanan yang jauh dan panjang dengan berbondong-bondong menyewa kendaraan hanya untuk menonton sang idolanya tampil (catatan lapangan). Hubungan yang dekat antara rombongan Rukun Karya dan para penggemarnya tentu saja tidak hanya muncul instan, tetapi telah berlangsung sejak lama dan dalam waktu yang cukup panjang.

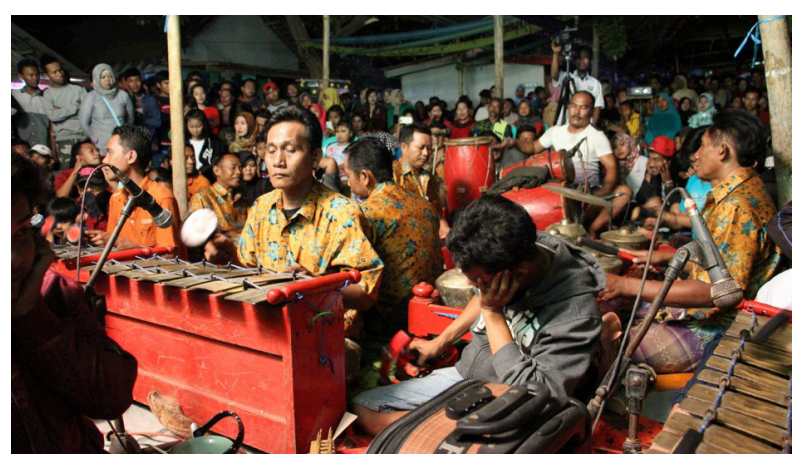

Gambar 1 Pemain Rukun Karya dikelilingi oleh Fans dan Penontonnya

Sumber: Dokumentasi Pribadi Tahun 2018

Helene Bouvier (2002) yang meneliti seni pertunjukan tradisional di Sumenep Madura pada tahun 1986-1987 mencatat sejarah dari kelompok seni tradisional ini secara singkat.

"Pada zaman Belanda, rombongan (kelompok) itu sudah ada dengan nama Rukun Santoso. Pertunjukan masih sederhana, tanpa dekor; mereka hanya bermain hanya untuk orang sekampung, dan yang dimainkan hanya sandiwara, bukan ketoprak. Jumlah anggotanya tiga puluh orang. Mereka mempunyai gamelan buatan Yogyakarta yang bagus sekali, terbuat dari adonan perunggu dan perak. Menjelang kemerdekaan tahun 1943, nama rombongan diganti menjadi Rukun Famili dan mereka beralih ke ketoprak. Mereka juga mengganti 
gamelan karena yang lama sudah rusak, dengan membeli gamelan dari Bondowoso (Jawa Timur) yang dibuat sekitar tahun '30-an, tetapi gamelan itu tidak sebagus yang lama. Pada tahun 1975 salah seorang anggota rombongan pergi magang $\mathrm{ke}$ rombongan ketoprak Siswo Budoyo selama kurang lebih satu bulan, di Jawa Timur. Dia kembali dengan berbagai gagasan teknis yang mulai diterapkan pada tahun 1977. Pada tahun 1975 rombongan pecah menjadi dua rombongan Rukun Famili dan Rukun Karya. Pada awalnya Rukun Famili mementaskan suatu campuran unsur ludruk dan ketoprak, tetapi kini hampir seluruhnya ketoprak. Pada musim kemarau, rombongan itu berpentas secara selangseling di Madura dan di Jawa Timur, dalam bahasa Madura, untuk masyarakat Madura.

Catatan Bouvier memberikan penjelasan yang cukup komprehensif bagaimana kelompok ini berdiri hingga akhirnya mencapai titik puncaknya. Ihwal yang paling penting adalah bagaimana kelompok seni tradisi ini bertahan dari zaman - ke zaman, dari zaman kolonial hingga zaman milenial. Perihal ini menunjukkan kualitas yang tetap dan terus dijaga serta bentuk kedinamisan kelompok ini dalam merespons setiap perubahan zaman. Dalam wawancaranya, Edi Suhandi yang saat ini merupakan pemilik dan ketua organisasi Rukun Karya mengatakan bahwa Rukun Karya didirikan oleh ayahnya yang bernama Muhammad Suharun pada 1 Januari 1976 di Desa Tanjung, Kecamatan Saronggi, Kabupaten Sumenep (Komunikasi Pribadi dengan Edi Suhandi, 12 Oktober 2020). Saat ini eksistensi kelompok Rukun Karya telah memasuki tahun ke-45 tahun. Usia yang cukup matang bagi sebuah kelompok seni tradisional. Berbekal kematangan mental dan pengalaman sejarahnya yang cukup panjang, Rukun Karya mampu bertahan hingga sekarang bahkan pada situasi yang cukup berat seperti pandemi Covid-19.

Ada beberapa hal yang membuat rombongan Rukun Karya tetap eksis, bertahan, dan tetap digandrungi oleh para penggemarnya dari masa ke masa. Ihwal yang pertama ialah perkara kedinamisan bentuk garapan. Melalui pengamatan pertunjukan di lapangan, rombongan Rukun Karya memiliki keunggulan dalam bidang penggarapan. Pertunjukan yang disajikan kepada masyarakat selalu memiliki aspek kebaruan, menghadirkan wacana-wacana yang baru dan segar, atau dapat dikatakan peka zaman, sehingga penonton selalu merasa penasaran dengan penampilan mereka setiap kali akan mengadakan pentas. Ihwal yang kedua ialah perkara pemahaman terhadap konteks masyarakat penontonnya. Lakon dan cerita yang dimainkan oleh rombongan Rukun Karya tidak pernah jauh dari kondisi terkini masyarakat setempat. Sebelum pentas, mereka sudah terbiasa untuk mengadakan riset kecil-kecilan di lingkungan setempat, dengan mengumpulkan informasi dari warga sekitar tentang kondisi masyarakat, isu terbaru dan karakteristik masyarakatnya. Informasi yang didapat kemudian digarap menjadi sebuah naskah yang relevan dan berhubungan dekat dengan kondisi masyarakat setempat. Pertunjukan yang menyajikan cerita yang dekat dan intim dengan pengalaman masyarakat akan selalu menghadirkan kesan mendalam pada penontonnya. Setiap pertunjukannya selalu menghadirkan lawakanlawakan yang kontekstual, yang barangkali akan berbeda dalam setiap pertunjukan. Ihwal yang ketiga adalah proses regenerasi yang berjalan dengan baik dalam organisasi. Dalam seni pertunjukan tradisi, seringkali menjadi terhambat dan mengalami kemunduran ketika proses regenerasi tidak berjalan dengan semestinya. Di rombongan Rukun Karya, proses regenerasi seniman masih cukup baik, dari segi umur dan pengalaman komposisinya masih seimbang antara yang senior dan junior. Ihwal yang keempat adalah proses komunikasi dan interaksi yang baik antara seniman dengan para penggemarnya. Rombongan Rukun Karya dinilai oleh para penggemarnya sebagai kelompok seni tradisi yang memiliki apresiasi dan simpati tinggi kepada masyarakat penontonnya. Terlihat ekspresi keakraban yang cukup intim yang dilakukan oleh para fans dan seniman di bawah panggung. Dalam setiap pentas, para seniman selalu menyebut satu per satu komunitas fans yang sudah hadir sebagai ungkapan rasa terima kasih dan apresiasinya. 
Maka tidak heran jika rombongan Rukun Karya memiliki banyak fans yang bertebaran di setiap tempat. Komunitas fans ini juga turut membangun eksistensi Rukun Karya hingga berkembang pesat sampai saat ini.

\section{Dari Panggung Tèropan Menuju Layar Virtual}

Rombongan Rukun Karya sebelumnya dikenal oleh masyarakat Madura sebagai kelompok seni ketoprak tradisional yang eksis dalam arena panggung-panggung tèropan, yang artinya napas kehidupan keseniannya bergantung pada satu tanggapan ke tanggapan lainnya dari acara hajatan pernikahan, selamatan desa, petik laut, dan lainnya. Seperti yang telah dijelaskan sebelumnya, tentang kedinamisan kelompok ini dalam merespons kemajuan zaman, membuat bentuk pertunjukannya selalu cair dan fresh untuk dinikmati secara terusmenerus. Beberapa ungkapan penonton yang selalu penulis dapatkan di lapangan adalah "ningghu Rukun Karya tadâ' busenna" (menonton Rukun Karya tidak pernah ada bosannya) (catatan etnografi). Kreativitas dan spontanitas yang dibangun di atas panggung menjadi ciri khas yang unik dari kelompok ini. Mereka cukup lihai dalam membangun interaksi dengan penonton, bahkan celetukan-celetukannya selalu kontekstual dengan kondisi masyarakat penontonnya. Terlihat dengan jelas jika mereka betul-betul menguasai pengetahuan perihal kondisi dan karakter masyarakat penontonnya. Selain itu, juga karena teknik penguasaan panggungnya yang sudah matang.

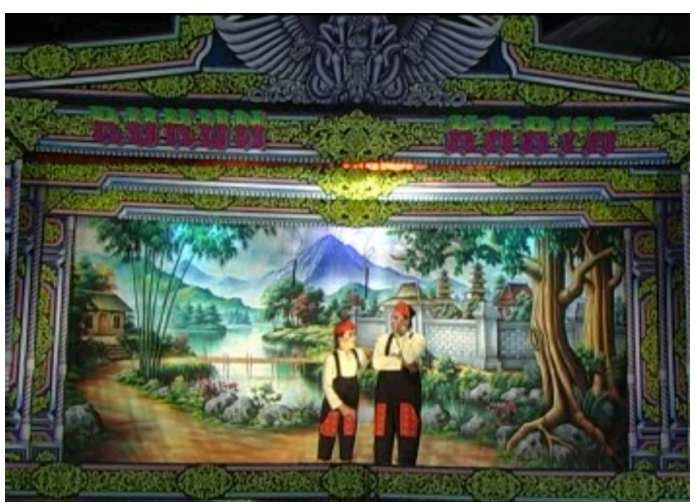

Gambar 2 Pertunjukan Ketoprak Rukun Karya Sumber: Cuplikan dalam VCD Rukun Karya berjudul Kalèbun Thok Thok
Sisi keunikan dan kelebihan ini kemudian harus dibayar mahal ketika pandemi datang dan masuk ke Indonesia pada awal tahun 2020. Pandemi memaksa mereka untuk meninggalkan pengetahuan lama yang telah mereka kuasai, dan mendorong mereka untuk menapaki suatu moda pengetahuan baru tentang seni pertunjukan dalam media daring. Semenjak pemerintah memberlakukan kebijakan social distancing, saat itu kelompok Rukun Karya mulai cemas karena hampir semua jadwal pentas/ tanggapan-nya dibatalkan oleh pengundang. Beberapa saat kemudian Dendi, yang merupakan anak dari Edi Suhandi membuat kanal Youtube bernama Dendi Ruka, saat itu konten yang diunggah masih berisi tentang rekaman pentas, dan vlog pribadi. Hingga kemudian Dendi terdorong untuk membuat konten Film komedi berdurasi pendek sekitar 20-30 menit per judul. Hingga pada 18 April 2020, ia mengunggah konten film komedi pertamanya yang diberi judul "Film Komedi Perkara Kambing 125 Juta dibuat Sate" dengan subtitle bahasa Indonesia. Konten ini berisi cerita komedi yang berlatar belakang konteks sosial masyarakat Madura, ditampilkan dengan menggunakan bahasa Madura dengan tambahan subtitle bahasa Indonesia. Perlu dijelaskan lebih dahulu bahwa film komedi Rukun Karya bukanlah sebuah film dalam pengertian konvensional. Secara teoretis film memiliki pengertian sebuah bentuk struktur yang memiliki akses dimensi vertikal dalam pembabakan prosedural pekerja hingga kekaryaannya (Widyarosadi, 2014:124). Sementara itu, film komedi Rukun Karya ialah sebuah karya videografi yang diciptakan untuk memenuhi kebutuhan konten dalam plartform Youtube. Secara konsep garapan (teknis), ia dikerjakan dengan sumber daya manusia yang terbatas, tidak memiliki kompetensi profesional dalam bidang sinematografi. Penggunaan terminologi film hanyalah sebagai penanda bahwa di dalam konten tersebut berisi konten video yang memiliki alur cerita layaknya sebuah film.

Pada kondisi pandemi, ketika pembatasan aktivitas publik diberlakukan oleh pemerintah, plartform Youtube hadir untuk menjadi penawar dan 
memberikan solusi alternatif kepada masyarakat baik untuk mencari informasi, mencari hiburan, belajar, berkomunikasi (media sosial), menceritakan kehidupan (vlog), maupun untuk berkreasi (berkesenian) ((Edy, 2017). Plartform Youtube saat ini telah mampu menyaingi dominasi televisi, bahkan banyak siaran televisi yang juga mereproduksi siarannya melalui Youtube. Berdasarkan bentuk dan aksesibilitas penggunaannya, Youtube memiliki beberapa karakteristik yang menarik di antaranya seperti (1) tidak ada batasan durasi untuk mengunggah video; (2) sistem pengamanan yang mulai ketat dan akurat; (3) memberikan peluang ekonomi bagi konten kreator; (4) memiliki fitur offline yang bisa diakses tanpa harus tersambung dengan jaringan internet; (5) tersedia fitur editing sederhana bagi para konten kreator (Faiqah, Fatty dkk, 2016:261). Selain itu, plartform Youtube juga memberikan kebebasan bagi para pengguna untuk dapat bebas berselancar mencari konten yang sesuai dengan minatnya. Dengan demikian, Youtube membuka peluang bagi konten-konten lokal yang dulunya sulit bersaing dengan dominasi konten di media arus utama. Konten lokal memiliki basis masanya sendiri, yaitu mereka merupakan penggemar setia yang selalu menunggu konten di kanal favoritnya. Ihwal ini sejalan dengan apa yang terjadi dalam film Rukun Karya. Kendati konten yang mereka garap kental dengan bentuk dan nuansa lokal, mereka tetap mendapatkan dukungan yang cukup besar dari penggemarnya di ranah lokal. Tidak menutup kemungkinan juga, yang lokal akan diminati oleh masyarakat di luar komunitas lokalnya. Dapat dilihat bagaimana konten-konten musik dangdut lokal berbahasa Jawa seperti yang digarap Denny Caknan justru mampu menempatkan namanya di jajaran artis nasional karena plartform Youtube.

Setelah konten komedi dalam plartform Youtube menuai banyak respons dari penggemarnya, lalu mereka secara konsisten membuat konten yang mereka sebut sebagai film komedi. Hingga saat ini jumlah konten film komedi yang diunggah di kanal Youtube Dendi berjumlah 115 konten film sejak bulan April 2020 hingga Maret 2021 dan telah mencapai 108 ribu subscriber (pelanggan). Kanal ini sempat beberapa kali berganti-ganti nama, dari Dendi Ruka, menjadi Edi n Dendi Ruka Channel (EDR Channel), kemudian saat ini telah berkembang menjadi dua kanal yang berbeda, yakni bernama Dendi Bogan dan Edi \& Dimas Ruka. Upaya ini tentu saja memberikan napas yang segar bagi kehidupan seniman tradisi yang sempat kehilangan panggungnya, dan kini mereka telah mendapat panggung yang baru meski sebatas panggung virtual. Pada November 2020, dalam sebuah wawancara, Edi Suhandi sempat memberikan pernyataan bahwa ide untuk membuat film komedi berangkat dari rasa keprihatinannya terhadap anggota kelompoknya yang kehilangan pekerjaan. Ia lalu mengajak beberapa anggotanya yang mau diajak kerja sama untuk bekerja menggarap konten film komedi. Saat diwawancara, Edi mengungkapkan bahwa penghasilan yang didapat dari Youtube memang tidak sebanyak saat mereka pentas secara langsung, tetapi setidaknya dapat meringankan beban para anggota senimannya (Edi Suhandi, wawancara pada 12 Oktober 2020).

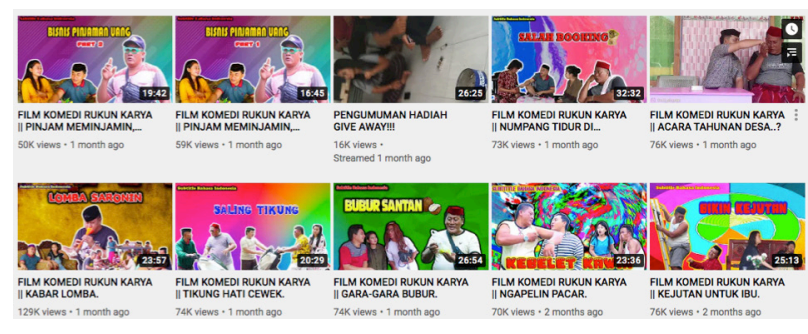

Gambar 3 Film Rukun Karya di Kanal Youtube Dendi Bogan

Sumber: Youtube Dendi Bogan

Film komedi Rukun Karya adalah sebuah moda pertunjukan yang baru bagi para pelaku seniman tradisi di rombongan Rukun Karya. Jika sebelumnya mereka berhadapan langsung (bertatap muka) dengan para penontonnya, kini aksi dan proses keaktoran mereka harus dimediasi oleh peranti rekam modern beserta media putarnya. Satu sisi mereka telah mengembangkan moda pertunjukan dari yang biasa mereka mainkan di atas 
panggung, di sisi yang lain mereka harus berjuang dan beradaptasi dengan ruang virtual yang tidak biasa mereka lakoni, bahkan harus mengorbankan pelbagai aspek pertunjukan sebagai konsekuensi artistiknya.

\section{Dari Tabbhuwân Ketoprak Menjadi Film Komedi}

Sebuah Peralihan Mode Pertunjukan

Film komedi Rukun Karya adalah bentuk pengembangan mode pertunjukan baru dari rombongan ketoprak Rukun Karya, dari yang biasa bermain di atas panggung pertunjukan dan dimainkan secara langsung (live) menjadi sebuah konten sinema yang dipublikasi dalam platform streaming online Youtube. Perubahan mode pertunjukan dari pertunjukan ketoprak menjadi film komedi merupakan sebuah proses mekanisme multimodalitas, alih wahana, dan media dalam seni pertunjukan. Menurut Damono (2012:1), alih wahana mencakup kegiatan penerjemahan, penyaduran, dan pemindahan dari satu jenis kesenian ke jenis kesenian lain. Wahana diartikan sebagai sebuah kendaraan, artinya alih wahana ialah proses perpindahan dari kendaraan satu ke kendaraan yang lain. Ada dua konsep tentang wahana, pertama wahana adalah medium yang dimanfaatkan atau dipergunakan untuk mengungkapkan sesuatu (gagasan/pikiran), kedua wahana adalah alat untuk membawa atau memindahkan sesuatu dari satu tempat ke tempat lain (Damono, 2012).

Lebih lanjut, Damono (2012:3) memberikan penjelasan antara wahana dan media bahwa setiap media adalah kumpulan dari wahana. Film adalah media sekaligus wahana, tetapi di dalamnya juga ada banyak wahana. Televisi juga media, dan di dalamnya juga tersusun beberapa elemen seperti musik dan film, yang keduanya juga dapat didefinisikan sebagai media. Keberadaan pelbagai media dalam satu media menunjukkan bahwa konsep 'media' sangat lentur, ihwal ini memberikan pengertian bahwa media tidak berdiri sendiri dan tidak dapat dipisahkan. Menurut Ellestrom (2010:8), Sebagai teks kultural ia bersifat mixed media, dalam pengertian bahwa pencampuran modalitas, dan media selalu merujuk pada konteks historis dan ideologis yang lebih luas.

Dalam konteks peralihan pertunjukan ketoprak menjadi film komedi, dapat dimaknai sebagai proses perubahan mode, yang di dalamnya penuh dengan percampuran dan negosiasi simbolsimbol budaya dan media (mixed media). Mode adalah cara mengerjakan sesuatu, sedangkan multimodalitas adalah pelbagai cara yang serempak dalam mengerjakan sesuatu. Ketoprak dan film komedi adalah sebuah teks multimodalitas yang tersusun atas pelbagai modalitas di dalamnya. Ketoprak Madura adalah kumpulan dari pelbagai media/modalitas seperti musik gamelan Madura, seni dekorasi, tari, resitasi, keaktoran, lakon, lawak, dan cerita-cerita kolosal. Film Komedi Rukun Karya adalah bentuk perubahan mode pertunjukan ketoprak Madura yang dipentaskan dengan perangkat multimodalitas yang kompleks menjadi mode pertunjukan sinema yang berhubungan dengan media perekaman audiovisual. Peralihan 'kendaraan' dari pertunjukan live di atas panggung menjadi sebuah konten sinema menghasilkan banyak konsekuensi artistik dan estetik. Kompleksitas dunia panggung akan dinegosiasikan dengan standardisasi konten film komedi pada platform Youtube.

Peralihan mode pertunjukan semacam ini sebetulnya sudah pernah dilakukan di beberapa masyarakat Madura, yakni dalam sinetron Madura yang pernah populer dan berkembang di lingkungan masyarakat Madura di Situbondo pada tahun 2000an (Hidayatullah, 2019). Sinetron Madura adalah produk rekaman berupa VCD yang diedarkan di lingkungan masyarakat Madura, berisi ceritacerita keseharian seputar konflik sosial masyarakat Madura dengan bentuk sinema elektronik berbahasa Madura. Seperti halnya film komedi Rukun Karya, sinema Madura adalah bentuk alih wahana dan media dari pertunjukan Al Badar, sebuah drama tradisional masyarakat Madura di Situbondo. Bedanya, jika sinetron Madura diproduksi dalam media VCD, film komedi Rukun Karya diproduksi dalam media digital Youtube. 
Guna memberikan penjelasan yang komprehensif tentang bagaimana peralihan mode dilakukan oleh rombongan Rukun karya, melihat konsekuensi-konsekuensi artistik yang terjadi serta bagaimana tarik-ulur negosiasi dalam proses produksinya, dan antisipasi dalam mengatasi konsekuensi artistik tersebut akan dijelaskan tentang analisis bentuknya pada pembahasan berikut,

Konteks Cerita Adaptasi

Berdasarkan jenis cerita yang ditampilkan oleh Rukun Karya dalam platform Youtube, ada dua macam kategori jenis film berdasarkan sumber dan konteks ceritanya. Jenis pertama adalah film dengan konteks cerita adaptasi, artinya film ini diciptakan dengan mengadapasi kisah atau cerita yang sudah ada (ketoprak, sastra, sejarah, dan televisi) ke dalam bentuk film komedi. Konsep adaptasi dalam film komedi Rukun Karya cukup efektif untuk diaktualisasikan, mengingat dalam pementasan pertunjukan ketoprak Madura, konsep ini selalu digunakan dalam proses kekaryaan. Penggunaan konsep adaptasi memiliki kecenderungan memudahkan para audiens/penonton dalam menangkap pesan dan makna dalam cerita yang digubah. Ketika menonton cerita adaptasi, mereka akan dibawa pada alam ingatan tentang sumber cerita awalnya, lalu 'memanggil' (indeksikalitas) ingatan (pengalaman) itu pada kontekstualisasi alam pertunjukan saat ini. Dalam kerangka semiotika Turino yang mengembangkan konsep Pierce, teknik ini dikenal dengan nama creative indexing (Turino, 1999:242). Konsep ini juga berlaku di dalam konteks film, sebagaimana yang diungkapkan oleh Lübecker dalam Banjarsari (2019:108), bahwa sebuah film dapat digubah sedemikian rupa dari yang seharusnya menghasilkan kesan buruk menjadi sebuah formula yang mempresentasikan realita tertentu.

Jenis kedua adalah film dengan konteks realitas masyarakat Madura, artinya film ini diciptakan dengan mengangkat kisah-kisah keseharian masyarakat Madura, dan yang menjadi sumber inspirasinya adalah kondisi masyarakat Madura terkini. Berikut akan diuraikan tentang jenis film dalam konteks cerita adaptasi yang bersumber dari (1) pertunjukan ketoprak Madura; (2) cerita sastra Timur-Tengah; (3) sejarah; dan (4) televisi.

1. Gaya dan Cerita Ketoprak Madura: Prabu Aki Kering vs Prabu Damar Strongking/Perebutan Dewi Sekar Abulilin

Film komedi Rukun Karya berjudul Prabu Aki Kering vs Prabu Damar Strongking/Perebutan Dewi Sekar Abulilin merupakan salah satu model film komedi Rukun Karya yang secara gaya, kostum, alur cerita, gaya tutur, tingkatatan bahasa, dan penokohan masih kental dengan gaya pertunjukan ketoprak Madura. Seperti halnya segmen cerita ketoprak Madura yang menampilkan adegan di keraton, konflik percintaan dan peperangan/ pertarungan, dalam film ini juga menggunakan format yang sama. Perbedaannya terlihat pada penggunaan nama dan istilah yang digunakan, seperti nama tokoh, nama kerajaan, dan tempat yang dipelesetkan serta menggunakan istilah-istilah yang lucu. Selain itu, perbedaannya juga terlihat pada penggunaan latar tempat yang tidak relevan dengan konteks cerita pada zaman dahulu, seperti menggunakan teras rumah sebagai istana keraton dan tegal sebagai lokasi pertempuran.

Ketidaksesuaian/keselipanyang tidakumum ditemukan dalam pertunjukan ketoprak Madura justru menjadi strategi baru dalam meraih simpati penggemar. Satu sisi mereka ingin memuaskan kerinduan para penggemar dengan cerita-cerita dan aksi mereka dalam pertunjukan ketoprak Madura, di sisi yang lain gaya ketoprak tersebut mereka jadikan sebagai bahan humor yang efektif, dengan cara menciptakan keselipan dan ketidakbiasaan simbol-simbol pertunjukan. Teknik ini merupakan salah satu cara yang dilakukan oleh para seniman Rukun Karya dalam mengantisipasi konsekuensikonsekuensi artistik yang muncul akibat peralihan mode pertunjukan dari ketoprak Madura menjadi film komedi. Pertunjukan ketoprak Madura memang tidak akan mampu untuk ditampilkan dengan nuansa dan 'rasa' yang sama dalam film, tetapi setidaknya ketidakmampuan akan terlihat sebagai hal yang unik di dalam pembentukan cita rasa film komedi 
Rukun Karya bertema ketoprak. Film komedi bertema ketoprak Madura ini juga menjadi penanda identitas kelompok Rukun Karya bahwa sejatinya mereka adalah seniman ketoprak. Berikut cuplikan dari film komedi Rukun Karya berjudul Prabu Aki Kering vs Prabu Damar Strongking.

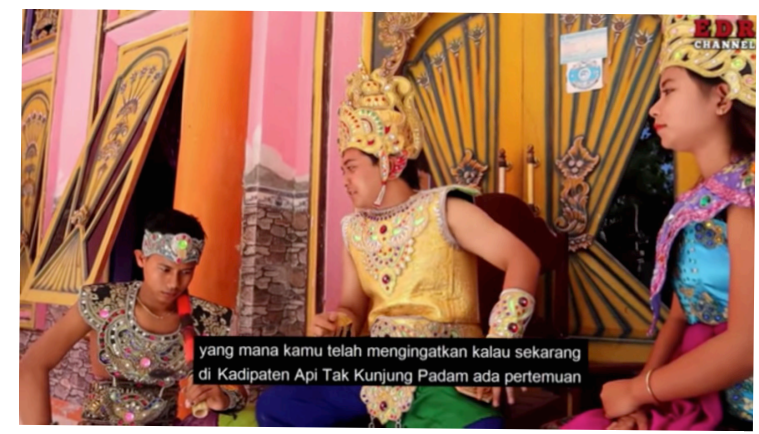

Gambar 4 Cuplikan Adegan Prabu Aki Kering di Istana Keraton

Sumber: Kanal Youtube Dendi Bogan

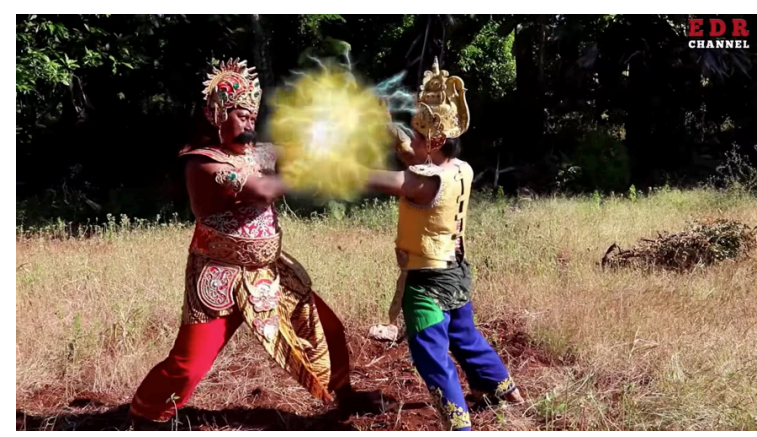

Gambar 5 Cuplikan Adegan Pertarungan Prabu Aki Kering vs Damar Strongking Sumber: Kanal Youtube Dendi Bogan

2. Cerita Aladin (Sastra Timur-Tengah): Teko Ajaib Part $1-4$

Film komedi Rukun Karya berjudul Teko Ajaib part 1 sampai part 4 adalah cerita serial empat episode yang mengisahkan seorang anak miskin yang sering dihina oleh kawan-kawan dan tetangganya, hingga suatu saat ketika ia diperintah oleh ibunya untuk mencari pakan ternak ia menemukan teko ajaib, yang di dalamnya berisi jin dan dapat mengabulkan tiga permintaannya. Cerita ini merupakan cerita adaptasi dari cerita Aladin yang dimodifikasi dan disesuaikan dengan konteks masyarakat dan lingkungan Madura. Bentuk perubahan terdapat dalam hal penamaan tokoh misal nama Jin yang menggunakan nama khas Madura, yakni Jin Ghundâl, latar tempat menggunakan lokasi pedesaan Madura, menggunakan bahasa Madura, dan konflik-konflik cerita yang berhubungan dengan kehidupan masyarakat Madura. Walaupun ada perubahan cerita, masih ada beberapa hal yang dipertahankan misalnya kostum tokoh Jin yang identik dengan pakaian Timur Tengah dan adegan cerita ketika Jin membantu tuannya dalam meraih hati seorang wanita yang dicintainya. Konteks adaptasi cerita dalam judul ini sama halnya dengan judul sebelumnya, yakni mengambil sebagian idiom cerita untuk kemudian diolah dan disesuaikan konteksnya dengan narasi lokal yang dekat dengan masyarakat Madura. Kontekstualisasi cerita ke dalam film komedi akan selalu menghadirkan bentuk-bentuk keselipan dan ketidaksesuian dengan cerita aslinya. Dalam konteks film komedi, keselipan justru menjadi ihwal yang penting dalam membangun narasi humor. Bentuk ketidakbiasaan bagi penonton akan menghadirkan pengalamanpengalaman yang unik dan menarik untuk disimak. Berikut cuplikan dari film komedi Rukun Karya berjudul Teko Ajaib Part 1: Jinnya Punya Identitas Juga.

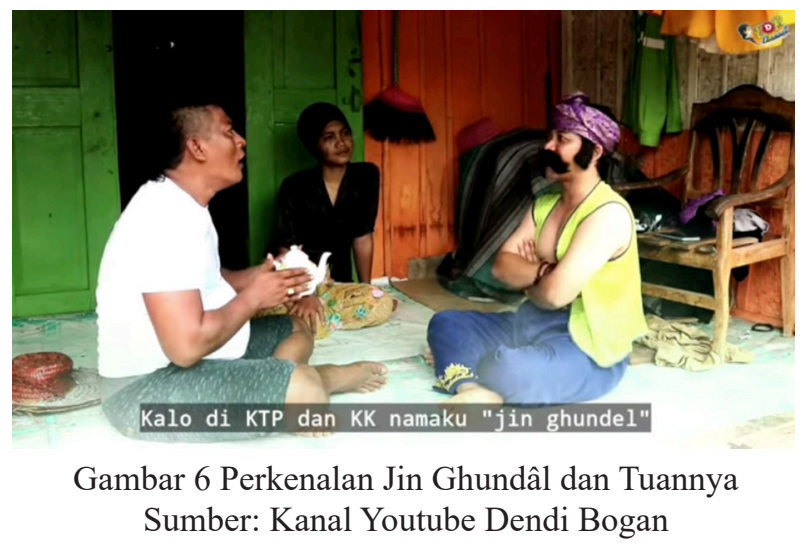

3. Cerita Perjuangan Kemerdekaan (Sejarah): Belanda Tunduk di Atas Kekuatan Indonesia

Film komedi Rukun Karya berjudul Belanda Tunduk di Atas Kekuatan Indonesia merupakan salah satu cerita sederhana yang mengisahkan narasi heroisme masyarakat lokal Madura melawan kolonialisme Belanda. Dalam cerita digambarkan kekejaman Belanda ketika masih menduduki wilayah di Madura. Kekejaman 
itu ditampilkan melalui adegan penyiksaan terhadap warga sipil (petani) melalui adegan membentak, menyiksa, dan memukul berkali-kali. Di sisi yang lain, juga digambarkan kegigihan masyarakat lokal Madura dalam menyusun strategi melawan Belanda, masyarakat lokal digambarkan sebagai masyarakat yang sederhana, bersenjata bambu runcing, dan berpakaian seperti masyarakat miskin (berbaju compang-camping). Ihwal yang menarik dari film ini ialah tentang bagaimana para seniman Rukun Karya mengungkapkan (mengekspresikan) pengalamannya tentang nasionalisme dan pandangannya terhadap wacana kolonial.

Alih-alih menggambarkan superioritas Belanda dengan atribut yang kejam, menakutkan, dan dominan, mereka justru menampilkan sosok Belanda yang dominan dengan atribut yang lucu bahkan 'menggelikan'. Belanda diperankan dengan sangat kacau, menggunakan logat bahasa yang tidak tepat, kostum yang tidak sesuai, dan diposisikan sebagai subjek yang kalah. Berikut cuplikan gambar pada film komedi tersebut,

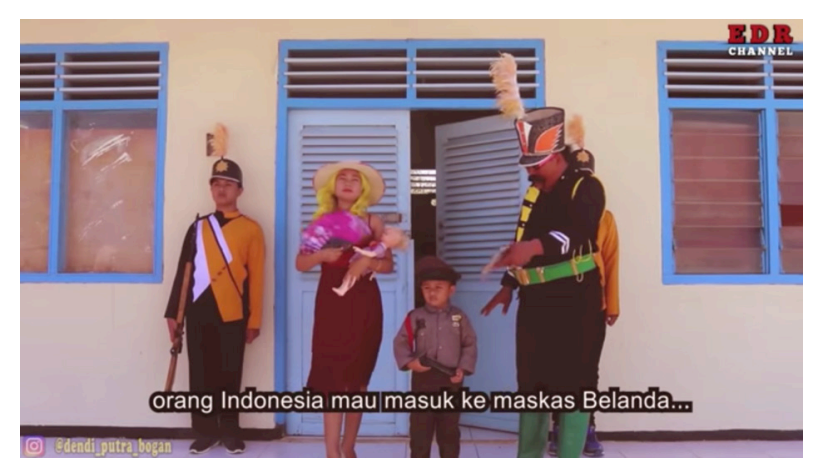

Gambar 7 Percakapan Kapten Belanda dengan Istri dan Anaknya

Sumber: Dendi Bogan

Pada gambar cuplikan 7 dapat diamati kostum yang dipakai oleh tentara Belanda dan keluarganya. Alih-alih menggunakan seragam tentara Belanda, mereka justru menggunakan seragam grup drum band ditambah dengan menggunakan sabuk (ikat pinggang) tradisional khas Betawi. Sebuah kombinasi kostum yang tidak akan mungkin dipakai oleh para tentara Belanda. Penggunaan kostum ini cukup membuat sistem penandaan subjek Belanda yang gagah perkasa menjadi kacau. Selain yang dipakai oleh tentara, kostum yang dipakai oleh sang anak juga terlihat 'aneh', alih-alih menggunakan kostum seorang anak Belanda, kostum yang dikenakan adalah kostum yang mirip dengan seragam polisi di Indonesia. Dalam perspektif poskolonial, kondisi ini disebut mimikri, sebuah proses kultural yang memberikan peluang agensi bagi masyarakat pascakolonial untuk memasuki dan menjalankan budaya dominan sekaligus bermain-main di dalamnya dengan menunjukkan subjektivitas yang menyerupai, tetapi menerimanya dengan tidak diam, tidak sepenuhnya sama (Bhaba, 1994:86). Mimikri selalu memunculkan ambivalensi sebagai bentuk kesadaran agensi yang memunculkan apropriasi dan inapropriasi kultural dalam medan kuasa (Setiawan, 2020:322).

Dalam konteks film Rukun Karya, episode ini merupakan ekspresi atau cara berbicara para seniman tradisi Madura (subordinat) melalui sikap peniruan (mimikri) terhadap tentara kolonial Belanda (dominan). Bhaba menjelaskan bahwa "meniru tidak berarti (sepenuhnya) mengekor karena dalam mimikri selalu terkandung unsur mengejek (mocery)" (Budiawan, 2010:xii). Meniru bisa diartikan sebagai sikap apresiasi/bentuk kekaguman, tetapi juga sekaligus melawan, bahwa subjek (seniman Rukun Karya) memiliki otonomi dalam memaknai kolonial Belanda. Otonomi atau agensi subjek dapat dikatakan sebagai sebuah pembangkangan terhadap nilai-nilai kolonial (disobedience). Mengejek (mocery) dalam film ini ditampilkan dengan jelas sepanjang cerita, dari ketidaksesuaian kostum, logat yang buruk, karakter Belanda yang buruk, dan sebagai subjek yang kalah. Wacana superioritas Belanda dalam film ini dikacaukan oleh sistem penandaan semiotik yang dikonstruksi oleh para seniman Rukun Karya.

4. Cerita Dunia Lain (Televisi): Uji Nyali Dunia Komedi

Film komedi Rukun Karya berjudul Uji Nyali Dunia Komedi merupakan konten film yang mengadaptasi konten serial televisi Uji Nyali dalam 
acara Dunia Lain yang disiarkan oleh salah satu stasiun televisi swasta di Indonesia. Secara konsep, film ini mengikuti gaya dan alur acara Dunia Lain, dengan menggunakan host (pembawa acara), seorang ustaz yang memiliki ilmu penerawangan makhluk gaib, narasumber, dan peserta uji nyali. Walaupun secara konsep memiliki kemiripan, seperti halnya bentuk-bentuk adaptasi film komedi sebelumnya, Rukun Karya selalu membuat hal-hal yang menarik perhatian penonton, seperti kostum pembawa acara yang hanya mengenakan celana pendek (terkesan tidak serius), kostum ustaz yang terlalu berlebihan (dengan jubah panjang, surban, dan membawa tasbih yang diikuti dengan gerak tangan seolah membacakan zikir), narasumber yang tidak relevan untuk acara uji nyali serta para peserta yang terlalu dramatis. Film menemukan klimaksnya ketika pada akhir acara tidak hanya peserta uji nyali yang kesurupan, tetapi juga ustaznya. Berikut cuplikan gambar dalam film komedi Rukun Karya berjudul Uji Nyali Dunia Komedi.

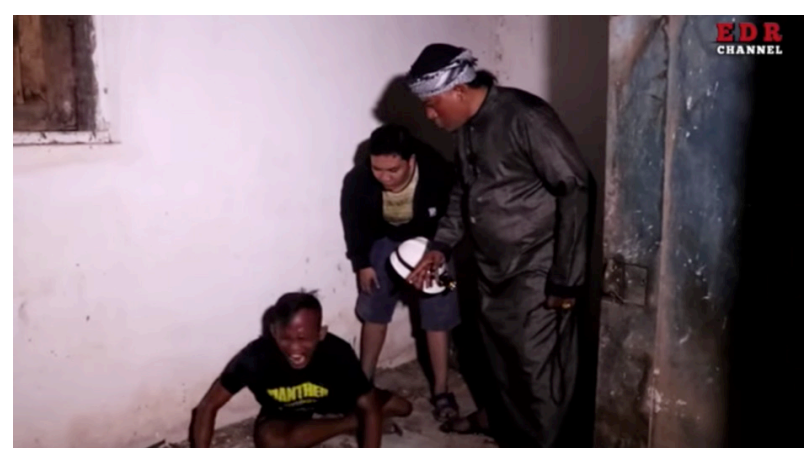

Gambar 9 Peserta Uji Nyali Kesurupan Sumber: Kanal Youtube Dendi Bogan

Konteks Cerita Berdasarkan Realitas Masyarakat Madura

Pada penjelasan sebelumnya telah dijelaskan bahwa salah satu jenis film Rukun Karya dalam konteks cerita adalah mengadaptasi pelbagai sumber seperti pertunjukan ketoprak Madura, sastra, sejarah, dan televisi. Pada subbab ini akan diuraikan jenis film Rukun Karya berikutnya, yakni berhubungan dengan konteks realitas masyarakat Madura. Dari ratusan film komedi Rukun Karya yang sudah dirilis di Youtube sebagian besar yang mendominasi adalah konten film yang berhubungan dengan realitas masyarakat Madura. Konten film berjenis ini memang dirasa paling populer dan paling dekat dengan masyarakat Madura. Wacana yang diangkat ialah seputar wacana keseharian masyarakat Madura, serta isu-isu terkini yang sedang merebak di media televisi dan media sosial.

Adapun beberapa contoh wacana yang diangkat salah satunya adalah mengenai pandemi Covid-19 seperti yang diartikulasikan dalam film komedi berjudul "Jamu Anti Lockdown", "GaraGara Corona", dan "Suntik Vaksin". Ketiga film ini menggambarkan situasi sosial dan budaya masyarakat Madura dalam menghadapi situasi pandemiCovid-19.Alih-alihmenggambarkansituasi yang kondusif dan ideal seperti harapan pemerintah, dalam film ini justru digambarkan dengan sangat gamblang bagaimana orang Madura di Sumenep memaknai pandemi. Banyak masyarakat yang kehilangan pekerjaan, TKW yang terpaksa diputus kontrak, persoalan utang, minimnya pengetahuan masyarakat tentang pandemi, dan situasi masyarkat yang hampir sebagian besar mengabaikan protokol kesehatan. Film ini memberikan refleksi kritis terhadap kondisi masyarakat Madura, sekaligus menjadi semacam ice breaking (pemecah kejenuhan) kepada masyarakat dalam menghadapi pandemi, bahwa pandemi memang sedang kita hadapi, tetapi semestinya kita menghadapinya dengan pikiran dan hati yang tenang serta gembira.

Selain wacana tentang Covid-19, film komedi Rukun Karya juga menyajikan beberapa wacana lainyangdekat dengankehidupanmasyarakat Madura seperti tentang penipuan, perselingkuhan, poligami, percintaan, polemik pinjaman bank, klenik perdukunan, konflik kemiskinan, rentenir, konflik tetangga, togel dan judi, premanisme, bahkan demam Tik Tok di kalangan anak muda. Semua wacana yang diangkat berdasarkan atas dasar refleksi dalam kehidupan masyarakat di sekitar sehingga konten Film Komedi ini selalu mendapat tempat di hati masyarakat. Melalui film komedi yang bercerita tentang realitas masyarakat sekitar, penonton seolah-olah diajak untuk mengurai 
pengalaman personal dan membaca pelbagai konflik-persoalan dirinya sendiri, melakukan refleksi atas lingkungannya, sekaligus menertawakan diri dan lingkungannya pada saat yang sama. Dalam konteks ini sebetulnya film komedi dan ketoprak Madura masih menjalankan prinsip yang sama, yakni menghadirkan pengalaman-pengalaman personal masyarakat Madura melalui sajian yang reflektif, kritis, dan ambivalensi. Cerita-cerita yang diangkat berdasarkan realitas masyarakat Madura sebetulnya juga dilakukan dalam pertunjukan ketoprak hanya bentuknya implisit, halus, dan diintregrasikan dengan simbol-simbol pertunjukan ketoprak, sedangkan dalam film komedi, persoalanpersoalan tersebut di-framing dan dihadirkan secara jelas dalam layar sinema. Berikut contoh cuplikan gambar dalam salah satu film yang berjudul Suntik Vaksin.

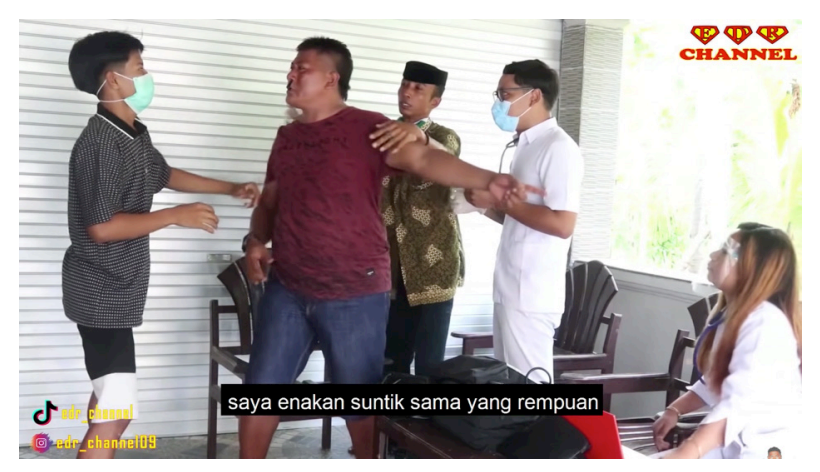

Gambar 10 Adegan Edi Disuntik Vaksin

Sumber: Kanal Youtbe Edi \& Dimas RUKA

\section{Konsep Penyajian Film Komedi Rukun Karya}

Industrialisasi Film Komedi Rukun Karya

Berdasarkan konsep penyajiannya, film komedi Rukun Karya menggunakan konsep penyajian model film pendek berdurasi sekitar 20 hingga 30 menit. Film ini hanya diputar dalam platform video streaming Youtube melalui dua kanal, yakni Dendi Bogan dan Edi \& Dimas RUKA. Film komedi Rukun Karya jika dibaca dalam perspektif industri budaya merupakan sebuah komoditas yang diproduksi untuk kepentingan ekonomis dan memiliki orientasi pasar yang luas. Maka dari itu, ketoprak Madura yang memiliki bentuk kompleks mengalami penyederhanaan supaya sesuai dengan standardisasi konten industri di platform online. Industri budaya menurut Adorno dan Horkheimer (Soetomo, 2003) merupakan mekanisme ketika sebuah komoditas mengalami produksi massal, reproduksi, dan penyebaran benda (produksi) budaya untuk kepentingan ekonomis. Ada tiga konsep budaya massa menurut Adorno yakni standardisasi, komodifikasi, dan massifikasi. Standardisasi dalam konsep Adorno adalah komoditas-komoditas yang menggunakan formula yang sama dengan sedikit modifikasi. Komoditas yang memiliki kesamaan disamarkan kesemaannya sehingga terlihat memiliki perbedaan. Dalam konteks film komedi Rukun Karya pola standardisasi dapat ditemukan dengan mudah seperti dalam adaptasi cerita Uji Nyali Dunia Komedi, Teko Ajaib, dan cerita lainnya. Rukun Karya juga menggunakan terminologi film komedi, bukan menggunakan istilah seni ketoprak atau istilah lokal Tabhuwân. Dalam setiap konten diberi subtitle (terjemahan) bahasa Indonesia, walaupun konteks ceritanya menggunakan bahasa Madura, serta durasi waktu yang mengikuti standardisasi sebuah konten dalam platform Youtube.

Pada film komedi Rukun Karya, konsep industrialisasi juga dapat dibaca melalui konsep komodifikasi. Adorno mengungkapkan bahwa komodifikasi objek budaya adalah komoditas budaya yang diproduksi oleh industri budaya dan dikendalikan oleh prinsip nilai tukar serta materialisme (profit oriented). Dalam konteks film komedi Rukun Karya, komodifikasi budaya terlihat dari motif peralihan mode pertunjukan ketoprak Madura menjadi konten film. Peralihan mode tersebut didasari oleh faktor ekonomi. Ketidakmampuan menggelar pertunjukan ketoprak akhirnya membuat para seniman berpikir ulang untuk melakukan komodifikasi bentuk seninya menjadi komoditas yang layak dijual di platform online.

Konsep berikutnya adalah massifikasi. Konsep ini dapat dibaca melalui bentuk media yang digunakan sebagai wadah publikasi film komedi Rukun Karya. Rombongan Rukun Karya menggunakan platform Youtube sebagai media 
untuk menyebarkan dan memublikasikan seluruh karya-karyanya. Saat ini platform youtube merupakan platform online yang cukup populer digunakan di Indonesia, bahkan eksistensinya telah menyaingi eksistensi media televisi. Pemilihan dan penggunaan platform Youtube dapat dibaca sebagai upaya untuk mewujudkan konsep massifikasi. Jika pada masa sebelumnya industri musik dan film menggandakan karya menggunakan VCD dan kaset, pada zaman ini konsep penggandaan/membagikan/ mendistribusikan karya-karya industri audiovisual cukup dengan men-share konten dalam platform Youtube.

Rombongan Rukun Karya tidak hanya melakukan peralihan mode pertunjukan, teta[I mereka juga mengembangkan model dan konsep penyajian serta mekanisme sistem keuntungannya berdasarkan platform online youtube. Jika dulunya mereka hanya mengandalkan undangan dari hajatan satu ke hajatan yang lain, saat ini mereka telah mengembangkan eksistensinya melalui produk industri budaya film komedi Rukun Karya.

Perubahan Penyajian dan Perubahan Menikmati Sajian

Peralihan mode pertunjukan tidak hanya memiliki dampak dalam teks pertunjukannya, tetapi juga berdampak dalam interaksi antara penampil dan penonton. Para seniman Rukun Karya yang sebelumnya memiliki kebiasaan bermain live di atas panggung dan berhadapan langsung dengan penontonnya, saat ini mereka harus membiasakan diri berakting berhadapan hanya dengan kru produksi dan tentu saja tanpa interaksi dialektis. Dalam pertunjukan ketoprak, sisi unikum dari rombongan Rukun Karya adalah ledakan-ledakan spontanitas yang hadir akibat interaksi dengan penonton. Ketika mereka bermain dalam film komedi, ledakan-ledakan spontanitas tersebut tidak dapat ditemukan lagi.

Di sisi penonton, mereka juga tidak bisa merasakan pengalaman menonton ketoprak secara kolektif/dalam jumlah penonton yang padat, riuh, ramai, dan seru. Saat ini ruang menonton yang kolektif diganti dengan ruang menonton yang privat melalui gadged (smartphone). Pergantian ruang kolektif menjadi privat juga membatasi ruang ekspresi penonton dalam merespons pertunjukan. Di ruang kolektif mereka dapat secara langsung berinteraksi dengan pemain ketoprak, mengejek, menyoraki, bahkan meneriaki jika ada yang salah, tetapi dalam ruang privat, ekspresinya tidak bisa diluapkan secara lues. Kendati dalam Youtube ada ruang untuk mengapresiasi lewat like dan comment, situasi dan pengalamannya pasti akan sangat berbeda.

Sebagian besar penonton film komedi Rukun Karya adalah para penggemar ketoprak Rukun Karya, sebagian lainnya ialah masyarakat komunitas Madura. Penonton yang terbiasa menikmati sajian ketoprak Madura semalam suntuk pasti akan merasakan banyak kehilangan pengalaman estetik yang kompleks ketika menonton dalam bentuk film komedi. Konsep pertunjukan ketoprak yang kompleks (gamelan Madura, tari, lawak, lakon, dekorasi, saweran, dan lagu dangdut) tidak akan sebanding dengan sajian film komedi yang secara konsep terpisah dari pelbagai aspek pertunjukan seni tradisi. Begitupun dengan para senimannya, walaupun film komedi memiliki peluang untuk ditonton lebih banyak dan ruang distribusinya jauh lebih dinamis dibanding pertunjukan ketoprak Madura, tetap tidak akan bisa menggantikan kompleksitas pertunjukan ketoprak Madura.

Ada beberapa hal yang masih dipertahankan oleh rombongan Rukun Karya ketika melakukan peralihan mode pertunjukan dari ketoprak Madura menjadi film komedi Rukun Karya, yakni mengenai aspek (1) wacana identitas lokal (Madura), ditunjukkan melalui penggunaan bahasa lokal, bercerita tentang konteks lokal, dan rasa kebanggaan terhadap identitas lokal Madura; (2) wacana sosialbudaya masyarakat Madura, ditunjukkan melalui kisah-kisah yang menarasikan kehidupan manusia Madura, tentang persoalan sehari-hari orang Madura, nilai kesederhanaan, konflik sosial, konflik rumah tangga, orang yang blak-blakan, orang yang lugu, 
serta orang yang emosional dan lucu; (3) wacana heroisme (nasionalisme), ditunjukkan melalui mengangkat cerita-cerita kepahlawanan seperti "Belanda Tunduk di Atas Kekuatan Indonesia", dan (4) Menampilkan pertunjukan yang reflektif, kritis, dan humoris dalam merespons situasi dan kondisi zaman.

\section{SIMPULAN}

Pandemi Covid-19 telah mengubah tatanan ekosistem seni pertunjukan di Indonesia secara signifikan. Seni pertunjukan tradisional merupakan kategori kelompok yang rentan dan cukup terimbas akibat kebijakan pelarangan mengadakan pertunjukan live oleh pemerintah. Rukun Karya adalah salah satu kelompok seni ketoprak (Madura) tradisional yang nyaris tenggelam pada masa pandemi. Berkat siasat dan strateginya beradaptasi dengan teknologi dan media, ia mampu bangkit dan meneguhkan kembali posisi eksistensinya. Rukun Karya menyiasati fenomena pandemi melalui strategi peralihan mode pertunjukan, secara perlahan dan konsisten ia mengalih-wahana (media) pertunjukan ketoprak tradisionalnya menjadi film komedi Rukun Karya.

Peralihan mode pertunjukan selalu menimbulkan konsekuensi artistik-estetik. Film komedi Rukun Karya mengalami penyesuaian mode pertunjukan berdasarkan mekanisme industri media (Youtube). Ketika pertunjukan ketoprak dialihwahanakan, ia akan menyesuaikan dengan standardisasi bentuk, struktur, tema, dan konten yang dikehendaki oleh industri. Film komedi Rukun Karya pada akhirnya lahir sebagai bentuk artikulasi seniman tradisional Madura yang baru dan unik. Kendati bersentuhan dengan mekanisme industri, wacana global, dan nasional, ia tetap mampu menegosiasikan identitas lokal kemaduraannya secara kuat. Narasi-narasi tentang lokalitas selalu menjadi kekuatan dan keunggulan dari konten film komedi tersebut.

Kondisi saat ini (2021), eksistensi Rukun Karya melalui film komedinya semakin menguat dan mendapat banyak respons positif dari para penggemarnya. Strategi peralihan mode pertunjukan pada rombongan Rukun Karya menjadi menarik untuk dikembangkan lebih lanjut, mengingat selama ini narasi tentang seni pertunjukan tradisional selalu dimaknai negatif, konservatif, dan tidak mampu berkembang. Pada kenyataannya para seniman tradisi mempunyai cara sendiri dalam mengembangkan bentuk keseniannya, terutama dalam memaknai modernitas dan bernegosiasi dengannya.

\section{KEPUSTAKAAN}

Banjarsari, T. (2019). Hal-Hal yang Absen dalam Pencatatan Mengenai Film Nasional. Jurnal Rekam, 15(2), 103-112.

Bhaba, H. K. (1994). The Location of Culture. London: Routledge.

Bouvier, H. (2002). Lèbur!: Seni Musik dan Pertunjukan dalam Masyarakat Madura. Jakarta: Yayasan Obor Indonesia.

Budiawan. (2010). Ambivalensi: Post-Kolonialisme Membedah Musik Sampai Agama di Indonesia. (Budiawan, Ed.). Yogyakarta: Jalasutra.

Damono, S. D. (2012). Alih Wahana. Jakarta: Editum.

Edy, C. (2017). Youtube, Citra Media Informasi Interaktif Atau Media Penyampaian Aspirasi Pribadi. Jurnal Muara Ilmu Sosial, Humaniora, Dan Seni, 1(2), 406-417.

Elleström, L. (2010). Media Borders, Multimodality and Intermediality. (L. Elleström, Ed.). London: McMillan.

Faiqah, Fatty., Nadjib, Muh., Amir, A. S. (2016). Youtube Sebagai Sarana Komunikasi Bagi Komunitas Makassarvidgram. Jurnal Komunikasi KAREBA, 5(2).

Hidayatullah, P. (2017). Ghending Dangdut: Artikulasi Budaya Masyarakat Madura dalam Seni Tabbhuwan. Resital: Jurnal Seni Pertunjukan. https://doi.org/10.24821/resital. v18i3.2244

Hidayatullah, P. (2019). Madurese Soap Opera: An Industry and Madurese Culture Migration of Situbondo People. Harmonia: Journal of 
Arts Research and Education. https://doi. org/10.15294/harmonia.v19i1.14951

Hidayatullah, P. (2020a). Post-Harmony Sangposangan as Dynamic Existence of Madurese People in Digital Era. Resital: Jurnal Seni Pertunjukan ISI Yogyakarta, 2l(1), 52-61.

Hidayatullah, P. (2020b). Tabbhuwân: Seni Pertunjukan Masyarakat Madura di Tapal Kuda. (M. Yoandinas, Ed.). Situbondo: Bashish Publishing.

Septiyan, D. D. (2020). Perubahan Budaya Musik di Tengah Pandemi Covid 19. Musikolastika, 2(1), 31-38.

Setiawan, I. (2020). Masa Lalu (Yang Belum Berlalu) Dalam Masa Kini: Membaca Ulang Pemikiran Pascakolonial Bhaba. In Gerak Kuasa: Politik Wacana, Identitas, dan Ruang/ Waktu dalam Bingkai Kajian Budaya dan Media (pp. 317-345). Jakarta: Kepustakaan Populer Gramedia.

Soetomo, G. (2003). Krisis Seni Krisis Kesadaran. Yogyakarta: Penerbit Kanisius.

Turino, T. (1999). Signs of Imagination, Identity, and Experience: A Peircian Semiotic Theory for Music. Ethnomusicology. https://doi. $\operatorname{org} / 10.2307 / 852734$

Widyarosadi, A. (2014). Ironi Setting Lokalitas dalam Film Komedi Jagad X Code: Kajian Sosiologi Pierre Bourdieu. Jurnal Rekam, 10(2).

Yoandinas, M., Hidayatullah, P., Farhan, M., Imron, M., \& Martiningsih, T. W. (2020). Tatèngghun: Realitas, Pengalaman dan Ekspresi Seni di Situbondo. (M. Yoandinas, Ed.). Situbondo: Bashish Publishing. 